\title{
Autolysis of dairy propionibacteria: isolation and renaturing gel electrophoresis of the autolysins of Propionibacterium freudenreichii CNRZ 725
}

\author{
R Lemée ${ }^{1}, \mathrm{~S}$ Lortal $^{1 *}$, J van Heijenoort ${ }^{2}$ \\ ${ }^{1}$ Laboratoire de recherches de technologie laitière, INRA, 65, rue de Saint-Brieuc, \\ 35042 Rennes cedex; \\ 2 Centre national de la recherche scientifique, Unité de recherche associée 1131 , \\ Université Paris-Sud, 91405 Orsay, France
}

\begin{abstract}
Summary - Dairy propionibacteria contribute to proteolysis and lipolysis of the curd in Swiss-type cheese technology by their autolysis and the concomitant release of intracellular enzymes such as esterases and peptidases. The spontaneous autolysis of $P$ freudenreichii CNRZ 725 just after maximal growth in sodium lactate broth was shown to occur at $\mathrm{pH} 6.0-6.2$, when the main carbon source (lactate) was depleted. This spontaneous autolysis was also observed with 6 other strains of $P$ freudenreichii, and its extent as well as its rate were clearly strain-dependent. The cell walls of $P$ freudenreichii CNRZ 725 were isolated by mechanical disruption and suspended in $0.05 \mathrm{~mol} / /$ potassium chloride at $40^{\circ} \mathrm{C}$. As they contained active autolysins, rapid cell wall lysis was observed in these conditions. Concomitantly, $15 \%$ of the cell wall proteins were released in the supernatant, as well as a high amount of neutral polysaccharides. The presence of autolysins among the released proteins was demonstrated by the lytic activity of the supernatant, and by renaturing gel electrophoresis. This method, applied here for the first time to analyse the autolysins of propionibacteria, revealed the complexity of their autolytic system. In P freudenreichii CNRZ 725, at least 8 lytic activities of various intensities and apparent molecular masses were observed: the most intense at $121 \mathrm{kDa}, 6$ very close activities between 81 and $118 \mathrm{kDa}$ and a rather weak and not completely translucent one at $34 \mathrm{kDa}$. Interestingly, all these activities were observed when the gels were incubated in Emmental juice instead of the optimal renaturation buffer $(0.1 \mathrm{~mol} / /$ potassium phosphate buffer $\mathrm{pH} 5.8,1 \% \mathrm{w} / \mathrm{v}$ of Triton $\mathrm{X}-100)$. Attempts made to separate and tentatively purify by chromatography (gel filtration, anion exchange) these 8 lytic activities from the supernatant of cell wall lysis were all unsuccessful. Finally, a method for extracting directly autolysins from whole cells was developed, using $1 \mathrm{~mol} / \mathrm{I} \mathrm{LiCl}$ solution. This $\mathrm{LiCl}$ treatment led to a crude extract of autolysins with a low content of contaminating neutral polysaccharides; however, the $34 \mathrm{kDa}$ lytic activity was seemingly missing in this extract.
\end{abstract}

propionibacteria / autolysis / autolysin / renaturing SDS-PAGE / cell wall

\footnotetext{
* Correspondence and reprints: Fax: 99285350/ e@mail: <lortal@labtechno.roazhon.inra.fr >
} 
Résumé - Autolyse des bactéries propioniques laitières : isolement et analyse sur gel d'acrylamide des autolysines de Propionibacterium freudenreichii CNRZ 725. Les bactéries propioniques laitières interviendraient dans la protéolyse et la lipolyse des fromages à pâte pressée cuite apres libération de leurs enzymes intracellulaires, par autolyse bactérienne. Dans un milieu de culture YEL, la phase d'autolyse spontanée de $\mathrm{P}$ freudenreichii CNRZ 725 débutant juste après la phase de croissance maximale, a lieu lorsque le $\mathrm{pH}$ du milieu de culture atteint 6,0-6,2 et que la principale source carbonée (lactate) est épuisée. L'ampleur de cette autolyse spontanée, également observée au cours de la croissance de 6 autres souches de $P$ freudenreichii, est un caractère souche-dépendant. Des parois de $\mathrm{P}$ freudenreichii CNRZ 725 préparées par rupture mécanique des cellules à la presse de French, sont placées dans une solution de chlorure de potassium à $0,05 \mathrm{molll}$, à $40^{\circ} \mathrm{C}$. Dans ces conditions, les autolysines associées à ces parois et encore dotées de leur activité, provoquent une hydrolyse pariétale rapide. Lors de cette hydrolyse $15 \%$ des protéines pariétales sont libérées dans le surnageant parallèlement à d'importantes quantités de polysaccharides neutres pariétaux. Parmi ces protéines libérées, la présence d'autolysines a été mise en évidence par mesure de l'activité lytique du surnageant et par analyse sur gel de polyacrylamide (SDS-PAGE) après renaturation des enzymes en présence de Triton $X-100$. Cette méthode, utilisée pour la première fois pour l'analyse des autolysines des bactéries propioniques, révèle la complexité de leur système autolytique. Chez $\mathrm{P}$ freudenreichii CNRZ 725, 8 activités lytiques d'intensité et de masses moléculaires apparentes variables ont été mises en évidence : une activité très intense de $121 \mathrm{kDa} ; 6$ activitès regroupées entre 81 et $118 \mathrm{kDa}$, et une activité plus diffuse et jamais totalement translucide de $34 \mathrm{kDa}$. De manière très intéressante, toutes ces activités sont observées lorsque le gel de polyacrylamide est directement incubé dans du jus d'emmental au lieu d'utiliser la solution de renaturation optimale (tampon phosphate de potassium à 0,1 moll, $p H 5,8$, a $40^{\circ} \mathrm{C}$, additionné de $1 \%(p / v)$ de Triton $\left.X-100\right)$. Les tentatives de séparation et de purification par chromatographie (filtration sur gel et échangeur d'anions) de ces 8 activités lytiques isolées du surnageant d'hydrolyse pariétale sont restées vaines. Néanmoins, une méthode d'extraction des autolysines directement des cellules entières, a été développée par l'utilisation d'une solution de $\mathrm{LiCl}$ à $1 \mathrm{~mol} / \mathrm{l}$. Ce traitement permet l'obtention d'un extrait brut d'autolysines pauvre en polysaccharides neutres. Mais l'activité de $34 \mathrm{kDa}$ est absente de cet extrait.

\section{bactérie propionique / autolyse / autolysine / SDS-PAGE suivie d'une renaturation / paroi}

\section{INTRODUCTION}

Autolysis is a spontaneous cell breakdown phenomenon. This process is carried out by endogenous cell wall located autolysins hydrolysing covalent bonds of the peptidoglycan, which is the main protective cell wall component (Rogers et al, 1980; Shockman and Höltje, 1994). Several autolysins of distinct specificity can be found at the same time in the cell wall and constitute the "autolytic system" of the bacteria.

The dairy propionibacteria (mainly Propionibacterium freudenreichii) are essential for the ripening of Swiss-type cheeses such as Emmental (Langsrud and Reinbold, 1973a, b; Bergère and Accolas, 1986;
Steffen et al, 1993), where they transform lactate into propionate and acetate with the concomitant production of $\mathrm{CO}_{2}$ which is essential for the formation of the expected opening of the cheese. Moreover, they contribute to the proteolysis and lipolysis of the curd by releasing intracellular enzymes after their autolysis. Indeed, intracellular esterases and peptidases have been shown in this genus (Langsrud, 1974; El Soda et al, 1991, 1992; Dupuis and Boyaval, 1993; Dupuis et al, 1993; Dupuis, 1994). Thus, the ability of a strain to autolyse could be a new characteristic to take into consideration when selecting starters for rapid and convenient ripening of cheese.

In 1974, Langsrud was the first to observe large differences between the 
induced autolyses of 6 strains of Propionibacterium freudenreichii (4), $P$ acidipropionici (1) and $P$ jensenii (1). More recently, we have compared the autolysis of 57 strains of dairy propionibacteria we have compared in $0.1 \mathrm{~mol} / /$ potassium phosphate buffer ( $\mathrm{pH} 6.2$ ), at $37^{\circ} \mathrm{C}$ (36 strains of $P$ freudenreichii; 5 strains of $P$ thoenii; 7 strains of $P$ acidipropionici and 9 strains of $P$ jensenii; the strains were from international collections and from industrial origin) (Lemée et al, 1994a). This study obviously confirmed the strain-dependent character of the autolysis phenomenon: 7 strains were shown to be highly prone to lysis (this represented $14 \%$ of the strains tested) and they belonged to the species $P$ freudenreichii, which is the principal species encountered in Swiss-type cheeses (Baer and Ryba, 1992). One of them, $P$ freudenreichii subsp shermanii CNRZ 725, was chosen as a model strain to further study autolysis (Lemée et al, 1994b). In sodium lactate broth (YEL), the maximal growth of $P$ freudenreichii CNRZ 725 was immediately followed by a spontaneous autolysis phase which was quantified by viability and cell dry weight measurements at different times, as well as visualized by transmission electron microscopy. During this spontaneous autolysis, cell walls were extensively damaged. On the other hand, the autolysis was induced in vitro by suspending harvested whole cells in appropriate buffers or salt solutions and the optimal conditions leading to extensive lysis were determined: $0.1-1 \mathrm{~mol} / \mathrm{l}$ potassium phosphate buffer, $\mathrm{pH} 5.8$ at $40^{\circ} \mathrm{C}$. Nevertheless, it must be stressed that, even reduced, the autolysis can be observed in a wide range of $\mathrm{pH}$ and temperature values (from 4 to $40^{\circ} \mathrm{C}$, and from $\mathrm{pH} 4.5$ to 8.5 ) (Lemée et al, $1994 b)$. These results, confirming previous observations of Langsrud (1974) using $P$ freudenreichii subsp shermanii P59, showed that autolysis of propionibacteria can occur at $\mathrm{pH}$ values and ionic strengths found in Swiss cheese.
When the cell walls of strain CNRZ 725 were isolated by mechanical disruption (French press) of exponential cells, their endogenous autolytic activity was at least partially preserved. Thus, a high level of cell wall lysis was observed when suspending them in the optimal conditions described earlier and the involvement of a major $\mathrm{N}$ acetylglucosaminidase activity was clearly demonstrated (Lemée et al, 1994b).

In this work, growth and subsequent spontaneous autolysis were followed up for several strains of dairy propionibacteria, and some experiments related to the effect of the temperature of growth and the role of lactate starvation on the induction of the phenomena are proposed. Nevertheless, this presentation is mainly concerned by the release of autolysin(s) of $P$ freudenreichii CNRZ 725 during the lysis of isolated cell walls, and their preliminary characterization; in particular, by using the efficient method recently described in the literature to visualize lytic enzymes after SDS-PAGE (Potvin et al, 1988; Leclerc and Asselin. 1989; Foster, 1991).

\section{MATERIALS AND METHODS}

\section{Bacterial strains and growth conditions}

Most of the strains were obtained from the CNRZ collection (INRA, Jouy-en-Josas) (CNRZ 725 . CNRZ 277, CNRZ 727) or from our collection (INRA, Rennes) (TL 12). Some strains (referred to as letters $\mathrm{M}, \mathrm{N}, \mathrm{P}$ and $\mathrm{T}$ ) were of commercial origin (Lemée et al, 1994a). The strain $P$ freudenreichii subsp shermanii CNRZ 725 appeared to be the most appropriate for studying autolysis. It showed the highest extent of autolysis in a potassium phosphate buffer $\left(0.1 \mathrm{~mol} / \mathrm{l}, \mathrm{pH} 6.2,37^{\circ} \mathrm{C}\right)$ compared with 56 other strains of dairy propionibacteria from our collection. Strains were stored at $-80^{\circ} \mathrm{C}$ in YEL (Malik et al, 1968) containing $15 \%(\mathrm{v} / \mathrm{v})$ glycerol. They were grown statically in YEL broth at $30^{\circ} \mathrm{C}$ for $2 \mathrm{~d}$ from a $1 \%(\mathrm{v} / \mathrm{v})$ inoculum of 2-d culture. Growth was monitored by mea- 
suring the optical density at $650 \mathrm{~nm}\left(\mathrm{OD}_{650}\right)$ using a spectrophotometer (Beckman DU 7400). For $\mathrm{OD}_{650}$ greater than 1, samples were diluted with distilled water. In order to maintain constant culture conditions (without stirring), a large volume of the culture freshly inoculated was distributed in tubes $(10 \mathrm{ml})$ which were used to measure $O D_{650}$ and viability at different times of the growth. Viability was determined on YEL agar plates after incubation for $5 \mathrm{~d}$ at $30^{\circ} \mathrm{C}$ under anaerobic conditions (Anaerocult A from Merck).

\section{Lactic, propionic and acetic acid concentrations}

Lactic, propionic and acetic acid concentrations were estimated using a high-performance liquid chromatography (HPLC) system (Beckman, USA) equipped with an UV detector $(214 \mathrm{~nm})$. Separation took place in a $7.5 \times 300 \mathrm{~mm}$ (Aminex A6, Biorad) stainless steel column, operated at ambiant temperature with $\mathrm{H}_{2} \mathrm{SO}_{4} 0.01 \mathrm{~mol} / \mathrm{I}$ $(1 \mathrm{ml} / \mathrm{min}$ ) as an eluent (Bio-Rad, 1987).

\section{Protein and neutral polysaccharide quantification}

The protein content was estimated by the Bradford (1976) procedure (Biorad microprocedure, Hercules, CA, USA) using serum albumin (Sigma) as standard. Neutral polysaccharides were quantified using the phenol-sulfuric acid method of Dubois et al (1956).

\section{Preparation of cell walls, the crude extract (CE) and the heat- treated cell walls}

The cell walls were obtained by mechanical disruption (French pressure cell) as follows: All operations were carried out at $4^{\circ} \mathrm{C}$. Cells were harvested at the beginning of the exponential growth phase by centrifugation at $5500 \mathrm{~g}$ for $15 \mathrm{~min}$, washed twice in distilled water and disrupted by 2 runs (15 and $5 \mathrm{~min}$ ) at $138 \mathrm{MPa}$ in a refrigerated French pressure cell (French and Milner, 1955). Undisrupted cells were removed by centrifugation at $5500 \mathrm{~g}$ for $15 \mathrm{~min}$. Cell walls were pel- leted by centrifugation at $30000 \mathrm{~g}$ for $15 \mathrm{~min}$, and washed at least 3 times with distilled water (Lemée et al, 1994b). In order to characterize the time course of cell wall lysis in buffer, we considered the extent of lysis expressed as the percent of decrease in $O D_{650}$ after $3 \mathrm{~h}$ of incubation. For the preparation of the crude extract, the cell walls were suspended in $0.05 \mathrm{~mol} / / \mathrm{KCl}$, at $40^{\circ} \mathrm{C}$ (2.4 mg dry weight $/ \mathrm{ml}$ ). After $90 \mathrm{~min}$ of incubation, the supernatant $(70 \mathrm{ml})$ was separated by centrifugation ( $35000 \mathrm{~g}, 15 \mathrm{~min}, 4^{\circ} \mathrm{C}$ ), dialysed against distilled water and concentrated to $10 \mathrm{ml}$ using an ultrafiltration cell (Amicon model 8200 , diaflo ultrafiltration membranes YM 10, cutoff Mr $10000,40 \mathrm{PSI}$ at $4^{\circ} \mathrm{C}$ ). The retentate was further concentrated to $1.5 \mathrm{ml}$ using centrifugal concentrators (Centricon 10, cutoff Mr 10000 ) at 5 $000 \mathrm{~g}$, and at $4^{\circ} \mathrm{C}$. This final concentrated retentate was centrifuged at $100000 \mathrm{~g}$ for $30 \mathrm{~min}$ at $4^{\circ} \mathrm{C}$ and has been called crude extract (CE).

In order to be used as substrates for the detection of the lytic activity in CEs, samples of cell walls were heated at $100^{\circ} \mathrm{C}$ for $10 \mathrm{~min}$ to completely denature their endogenous autolytic activity (Lemée et al, 1994b).

\section{Purification of the autolysins}

\section{Ammonium sulfate precipitation}

The precipitation of the CE by ammonium sulfate was carried out according to the table of Dawson et al (1969). Precipitation was performed at $4{ }^{\circ} \mathrm{C}$, during $15 \mathrm{~h}$. The precipitated proteins were sedimented by centrifugation $(30000 \mathrm{~g}$. 15 min at $4^{\circ} \mathrm{C}$ ).

\section{Chromatography}

All the purification steps were performed on a Pharmacia (Upsala, Sweden) FPLC system. Samples were applied to a Superose 12 HR 10/30 column $(1 \times 30 \mathrm{~cm})$ previously equilibrated with $50 \mathrm{mmo} / /$ potassium phosphate buffer, $\mathrm{pH} 5.8$, containing $0.5 \mathrm{~mol} / \mathrm{KCl}$. The column was eluted with 1 bed volume of the same buffer at a flow rate of 0.5 $\mathrm{ml} / \mathrm{min}$. The CE or enzyme fraction was applied to a prepacked Mono Q HR $5 / 5$ column ( $1 \times 5 \mathrm{~cm}$ ), a strong anion-exchanger, previously equilibrated with $10 \mathrm{mmol} / \mathrm{l}$ potassium phosphate buffer, $\mathrm{pH}$ 5.8 or 8.0 . Elution was at a flow rate of $1 \mathrm{ml} / \mathrm{min}$ 
using a linear $\mathrm{KCl}$ gradient ( 0 to $1 \mathrm{~mol} / \mathrm{l}$ over $25 \mathrm{~min})$.

The column was monitored on the basis of $A_{280 \mathrm{~nm}}$ and $A_{260 \mathrm{~nm}}$ and $1.0 \mathrm{ml}$ fractions were collected. Portions of each fraction, or pooled fractions, were concentrated through a Centricon-10 (cutoff Mr 10000 ) or Centricon-3 (cutoff Mr 3000 ) and tested for lytic activity.

\section{Assay for lytic activity}

The standard assay was done as follows: Autoclaved $\left(121^{\circ} \mathrm{C}, 15 \mathrm{~min}\right)$ whole cells of CNRZ 725 where suspended in $0.1 \mathrm{~mol} / \mathrm{l}$ potassium phosphate buffer, at pH $5.8(0.21 \mathrm{mg}$ cellular dry weight $/ \mathrm{ml}$ equivalent to an $\mathrm{OD}_{650}$ of 0.9 ). One hundred $\mu \mathrm{l}$ of autolysins containing sample were added to $1.9 \mathrm{ml}$ of this cell suspension.

One unit of lytic activity (UA) was defined as the quantity of enzyme which reduced the turbidity of this whole cell suspension by 0.001 $O D_{650} / \mathrm{min}$ during the first $15 \mathrm{~min}$ incubation at $40^{\circ} \mathrm{C}$. The specific activity was defined as the lytic activity per $\mathrm{mg}$ of proteins (UA/mg proteins).

\section{Extraction of autolysins from whole cells}

\section{Using LiCl}

Exponential cells of CNRZ 725 were washed twice with distilled water and suspended in a precooled $1 \mathrm{~mol} / \mathrm{L} \mathrm{LiCl}$ solution $(7 \mathrm{mg}$ cellular dry weight $/ \mathrm{ml}$ ). The suspension was gently stirred for $3 \mathrm{~h}$ at $4^{\circ} \mathrm{C}$ and centrifuged at $5500 \mathrm{~g}$ for $15 \mathrm{~min}$ at $4^{\circ} \mathrm{C}$. The supernatant was then dialysed at $4^{\circ} \mathrm{C}$ against 21 of distilled water for $72 \mathrm{~h}$ (using Spectrapor molecular porous membrane tubing, cutoff Mr 6 000-8 000). The enzymatic extract was then concentrated using an ultrafiltration device (Centricon 30 , cutoff Mr 30 000).

\section{Using SDS}

Exponential growth phase cells were washed twice with distilled water and suspended at room temperature in 1\% SDS solution (1 mg cellular dry weight/ml). The suspension was gently stirred for $16 \mathrm{~h}$ at room temperature and centrifuged at $5500 \mathrm{~g}$ for $15 \mathrm{~min}$ at $4^{\circ} \mathrm{C}$. The supernatant was then dialysed at $4^{\circ} \mathrm{C}$ against $2 \mathrm{I}$ of distilled water for $72 \mathrm{~h}$ (using Spectrapor molecular porous membrane tubing, cutoff Mr $6000-8000$ ). The enzymatic extract was then concentrated by evaporation using a speed vacuum apparatus (Savant Instrument), and stored at $-20^{\circ} \mathrm{C}$.

\section{Renaturing SDS-PAGE, SDS-PAGE and sample preparation}

The renaturing polyacrylamide gel electrophoresis (renaturing SDS-PAGE) was similar to that described by Potvin et al (1988), Leclerc and Asselin (1989) and Foster (1991), with some modifications which will be described elsewhere. Denaturing $0.1 \%(\mathrm{w} / \mathrm{v})$ sodium dodecyl sulfate (SDS)-polyacrylamide separating gels ( $10 \%$ acrylamide in $370 \mathrm{mmol} / \mathrm{l}$ Tris-HCl buffer, $\mathrm{pH} 8.8$ ) containing $0.2 \%(\mathrm{w} / \mathrm{v})$ whole cells of $P$ freudenreichii CNRZ 725 previously autoclaved at $121^{\circ} \mathrm{C}$ for $15 \mathrm{~min}$ in distilled water, were used to detect lytic activity.

Gels (minigels) were subjected to electrophoresis at $150 \mathrm{~V}$ of constant voltage for approximately $2 \mathrm{~h}$, under a continuous SDS-Trisglycine buffer system $(0.1 \%$ [w/v] SDS, $25 \mathrm{mmo} / /$ Tris, $192 \mathrm{mmol} / /$ glycine, $\mathrm{pH}$ 8.3). After electrophoresis, gels were soaked for $30 \mathrm{~min}$ in distilled water at room temperature with gentle shaking. The gels were then transferred in $0.1 \mathrm{~mol} / \mathrm{l}$ potassium phosphate buffer, $\mathrm{pH} 5.8$, containing $1 \%(w / v)$ Triton $X-100$ (the renaturation solution, except if stated otherwise). The gels were gently shaken for $16 \mathrm{~h}$ at $40^{\circ} \mathrm{C}$ to allow renaturation. Following incubation, the gels were rinsed with distilled water, stained in $0.1 \%(\mathrm{w} / \mathrm{v})$ methylene blue in $0.01 \% \mathrm{KOH}$ (according to Jayaswal et al, 1990) for at least $3 \mathrm{~h}$, and destained in distilled water. The lytic activities were visualized as translucide bands in the blue background.

For SDS-PAGE or renaturing SDS-PAGE, samples were prepared identically as follows: The samples were mixed volume to volume with the Laemmli buffer $(62.5 \mathrm{mmo} / / \mathrm{Tris}-\mathrm{HCl} \mathrm{pH} 6.8$, containing $10 \%[\mathrm{v} / \mathrm{v}]$ glycerol and $2 \%[\mathrm{w} / \mathrm{v}] \mathrm{SDS}$, $5 \%$ [v/v] $\beta$-mercaptoethanol, $0.025 \%[\mathrm{w} / \mathrm{v}]$ bromophenol blue). Samples were boiled for $2 \mathrm{~min}$ and loaded onto the gels. As all electrophoreses were run in denaturing conditions, the apparent $\mathrm{Mr}$ of the proteins as well as of the lytic bands observed could be estimated. The calibration proteins used ranged from 14400 to 212000 (Low Molecular Weight Calibration Kit; Pharmacia: 
phosphorylase B [94 kDa], bovine serum albu$\min [67 \mathrm{kDa}$ ], ovalbumin [ $43 \mathrm{kDa}$ ], carbonic anhydrase [30 kDa], soybean trypsin inhibitor [20.1 $\mathrm{kDa}$ ], $\alpha$-lactalbumin [14.4 kDa] and High Molecular Weight Calibration Kit; Pharmacia: myosin [212 kDa], $\alpha 2$-macroglobulin [170 kDa], $\beta$-galactosidase [116 kDa], transferrin [76 kDa] and glutamic dehydrogenase [53 kDa]).

In renaturing SDS-PAGE, the lane containing the standard was cut and stained by Coomassie Blue R250. For the protein analysis by SDSPAGE (Laemmli, 1970), gels were stained with Coomassie Blue R 250 and silver nitrate according to Tunon and Johansson (1984). All observations were confirmed in at least 2 independent experiments.

\section{RESULTS}

\section{Spontaneous autolysis after maximal growth}

Previous work (Lemée et al, 1994a) showed that the extent of autolysis observed by suspending exponential phase cells in phosphate buffer was highly strain-dependent. Two clusters were defined: cluster A containing 7 strains highly prone to lysis (with an average decrease of $\mathrm{OD}_{650}$ about $31 \pm 10 \%$ in $2 \mathrm{~h}$ and $86 \pm 5 \%$ in $24 \mathrm{~h}$ ) and cluster $\mathrm{B}$ containing the 50 other strains. In addition, the complete growth curve of 1 of the strains belonging to cluster A ( $P$ freudenreichii CNRZ 725) was studied and showed a spontaneous large autolysis just after maximal growth. In order to see whether the autolysis in phosphate buffer could be correlated with a more or less extensive spontaneous autolysis in broth, the growth of 5 cluster A strains and 3 cluster B strains was followed under the same conditions (figs 1a and $\mathrm{b}$, respectively). All cultures presented a decrease of $O D_{650}$ just after the maximal growth. The absence of any stationary phase, or the presence of only a very limited one, has already been observed in propionibacteria (Langsrud, 1974; de Carvalho,
1994; Lemée, 1994), and could thus be a general feature of their growth in YEL medium. Nevertheless, the comparison of these 2 graphs revealed that the rate and final extent of the spontaneous autolytic phase were obviously more important for the strains belonging to cluster A compared to those of cluster B, while their exponential growth phases were virtually identical. It could therefore be concluded that the screening in phosphate buffer gives a valuable indication about the ability of a given strain to autolyse extensively after its maximal growth. Nevertheless, this assessment should be confirmed by analyzing a larger number of cluster B-type strains.

Using our model strain, $P$ freudenreichii CNRZ 725, the influence of the temperature of incubation $\left(15,24\right.$ and $\left.30^{\circ} \mathrm{C}\right)$ on its growth and on the subsequent spontaneous autolysis phase was studied (fig 2). At these 3 temperatures, the maximal $O_{650}$ was about 3 (corresponding to $510^{9} \mathrm{cfu} / \mathrm{ml}$; data not shown) and spontaneous autolysis occurred more rapidly the higher the temperature was. The rates of the $O_{650}$ decrease (expressed in $\mathrm{uOD} / \mathrm{min}$ ) were 0.27 $10^{-4}, 2.810^{-4}$ and $3.810^{-4}$ at 15,24 and $30^{\circ} \mathrm{C}$, respectively. At $37^{\circ} \mathrm{C}$, which is even closer to the optimal temperature of the autolytic system of the strain $\left(40^{\circ} \mathrm{C}\right)$, no significant growth was observed. Interestingly, if samples of the cultures at $30^{\circ} \mathrm{C}$ where transferred to $43^{\circ} \mathrm{C}$ during the exponential phase $\left(\mathrm{t}=41 \mathrm{~h} ; \mathrm{OD}_{650}=2.2\right)$, spontaneous autolysis occurred immediately at a rate of $1.810^{-4} \mathrm{uOD} / \mathrm{min}$ (data not shown).

Because spontaneous autolysis in the growth medium is often related to a nutrient starvation, the contents of lactate, propionate and acetate, as well as the $\mathrm{pH}$, were followed during the growth of CNRZ 725 on YEL at $30^{\circ} \mathrm{C}$ (fig 3 ). The acidification of growth medium was concomitant with the organic acid productions. The starting point of the spontaneous autolysis corresponded effectively to a consumption of $95 \%$ of the 

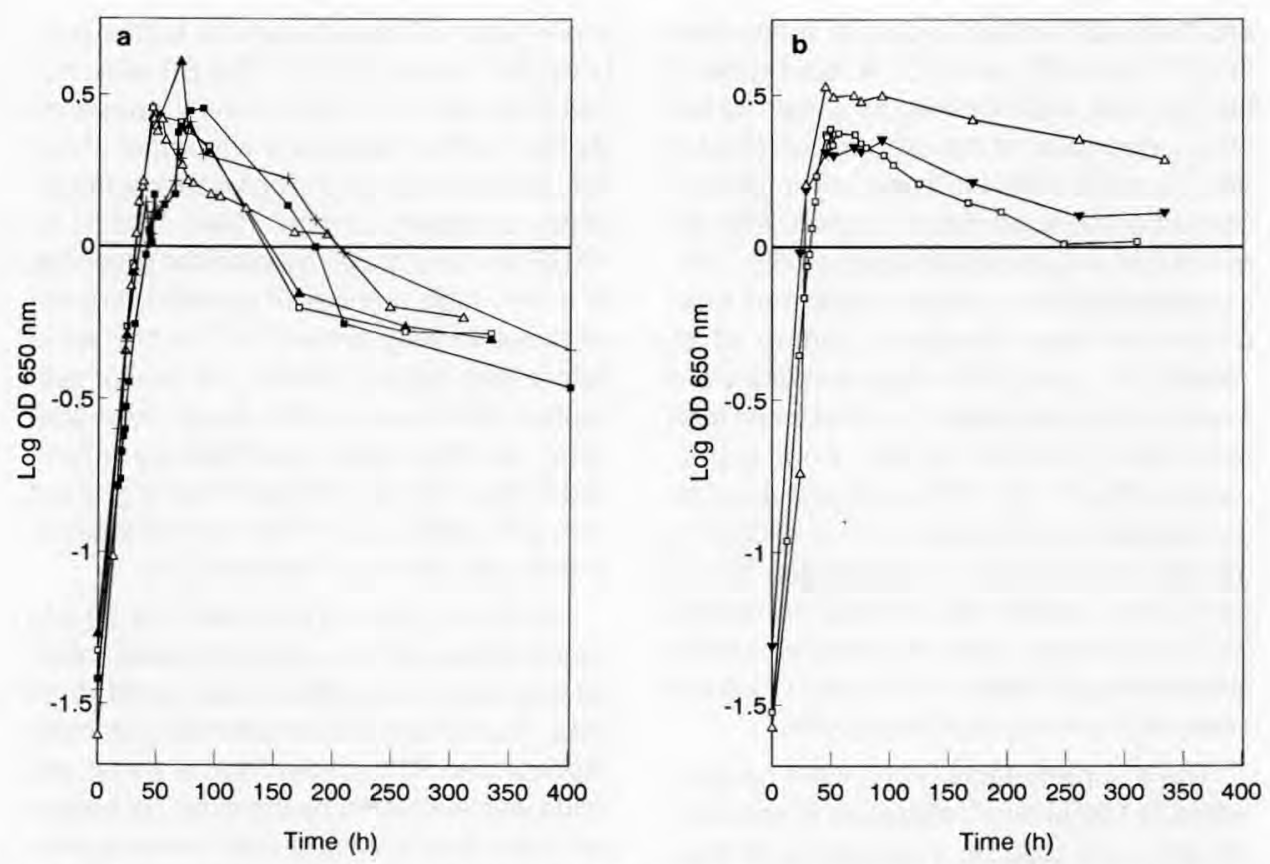

Fig 1. Comparison of the growth curves $\left(\log \mathrm{OD}_{650}\right)$ in $\mathrm{YEL}$ medium at $30^{\circ} \mathrm{C}$, of (a) dairy propionibacteria strains highly prone to autolysis in potassium phosphate buffer (cluster $A$, strains: CNRZ $725, \mathbf{E} ;$ CNRZ 727, +; TL 12, $\Delta ; \mathrm{P}, \square ; \mathrm{T}, \mathbf{\Delta}$ ) and (b) strains more resistant to autolysis (cluster B, strains: CNRZ 277, $\square ;$ M, $\Delta ;$ N, $\mathbf{\nabla})$.

Comparaison des courbes de croissance $\left(\log D O_{650}\right)$ en milieu de culture $Y E L$ à $30^{\circ} \mathrm{C}$ (a) de souches de bactéries propioniques laitières présentant une forte autolyse en solution tamponnée de phosphate de potassium (groupe $A$, souches : CNRZ 725, $\boldsymbol{\theta} ;$ CNRZ 727, $+; T L 12, \Delta ; P, \square ; T, \mathbf{\Delta}$ ) et (b) de souches plus résistantes à cette autolyse induite (groupe $B$, souches : CNRZ 277, $\square ; M, \Delta ; N, \boldsymbol{\nabla}$ ).

initial lactate content and occurred at $\mathrm{pH}$ 6.2. From the beginning of spontaneous autolysis, the metabolism of lactate as well as the production of propionic acid (maximum concentration of $5 \mathrm{~g} / \mathrm{l}$ ) or acetic acid (maximum concentration of $2.6 \mathrm{~g} / \mathrm{l}$ ) were stopped. If the depletion of lactate is the principal inducing factor of cell autolysis, providing lactate during the lytic phase should arrest the phenomena. Effectively, the addition of lactate alone (to a final concentration identical to that of YEL medium, $10 \mathrm{~g} / \mathrm{l})$ ) at the end of the exponential growth phase, as well as during the spontaneous autolysis, induced immediately a new growth of strain CNRZ 725 (data not shown) and this was verified for another strain (CNRZ 277) belonging to the cluster $B$ (data not shown).

\section{The autolytic system of $\mathrm{P}$ freudenreichii CNRZ 725}

\section{Release of the autolysin(s) during the lysis of isolated cell walls; obtention of a CE of autolysin(s)}

The cell walls of $P$ freudenreichii CNRZ 725 were isolated as described in the Materials 
and Methods section, and were suspended in $0.05 \mathrm{~mol} / / \mathrm{KCl}$ at $40^{\circ} \mathrm{C}$. A rapid lysis of the cell walls was obtained as shown by the $\mathrm{OD}_{650}$ decrease of the suspension (fig $4 \mathrm{a}$ ) and paralleled the increase of the protein content of the supernatant fraction. After 90 min of cell wall lysis (at this stage $55 \pm 7.7 \%$ of peptidoglycan amino acids and hexosamines were liberated; Lemée et al, 1994b), $57 \mu \mathrm{g}$ eq BSA of proteins $/ \mathrm{ml}$ were found in the supernatant, and this value then remained constant (fig $4 a$ ). Four supernatants $(\mathrm{S} 0, \mathrm{~S} 1, \mathrm{~S} 2, \mathrm{~S} 3)$ were recovered by centrifugation $\left(35000 \mathrm{~g}, 15 \mathrm{~min}, 4^{\circ} \mathrm{C}\right)$ at 0 , 40,90 and $150 \mathrm{~min}$, respectively. It was noted that sample SO already contained $21.7 \mu \mathrm{g}$ of protein per $\mathrm{ml}$, released just by suspending cell walls in $\mathrm{KCl}$ at $40^{\circ} \mathrm{C}$ without seemingly yet any significant lysis.

The 4 supernatants $(2 \mathrm{ml})$ were concentrated to $100 \mu \mathrm{l}$ by ultrafiltration (Centricon30 ) and were added to a suspension of heattreated cell walls $\left(10 \mathrm{~min}\right.$ at $\left.100^{\circ} \mathrm{C}\right)$ in 0.1 $\mathrm{mol} / \mathrm{l}$ potassium phosphate $\left(\mathrm{pH} 5.8\right.$ at $40^{\circ} \mathrm{C}$, $0.6 \mathrm{mg}$ wall dry weight/ml). The 4 concentrated supernatants were able to hydrolyse the heated cell walls (fig $4 \mathrm{~b}$ ), indicating that they all contained some autolysin(s). The supernatant S2 was chosen for further purifying the autolysin(s). The S3 was not retained even if its lytic activity appeared slightly higher because it was much more contaminated by peptidoglycan fragments (data not shown; Lemée, 1994). The SDSPAGE analysis of $S 2$ revealed the presence of a very high number of proteins, but not all those initially present in the cell walls before lysis (fig $4 \mathrm{c}$ ). Indeed, the total protein content (estimated by the Bradford procedure) was $380 \mu \mathrm{g} / \mathrm{mg}$ of cell wall dry weight, and it could thus be estimated that only about $15 \%(57 \mu \mathrm{g} / 380 \mu \mathrm{g})$ of this content was liberated after $90 \mathrm{~min}$ of cell wall lysis.

For the purpose of purification, a 30-fold concentration of the volume of supernatant $\mathrm{S} 2$ was obtained by ultrafiltration (cutoff $\mathrm{Mr} 10$ $000)$. The activity recovered in the retentate represented $92 \%$ of the total activity; this value was estimated by the extent of heated cell walls lysis obtained after concentration (percent decrease of $\mathrm{OD}_{650}$ after $3 \mathrm{~h}$ of incubation) (data not shown). The retentate was named crude extract (CE) for all subsequent purification and characterization steps.

Further biochemical analysis of CE revealed a very high content of neutral

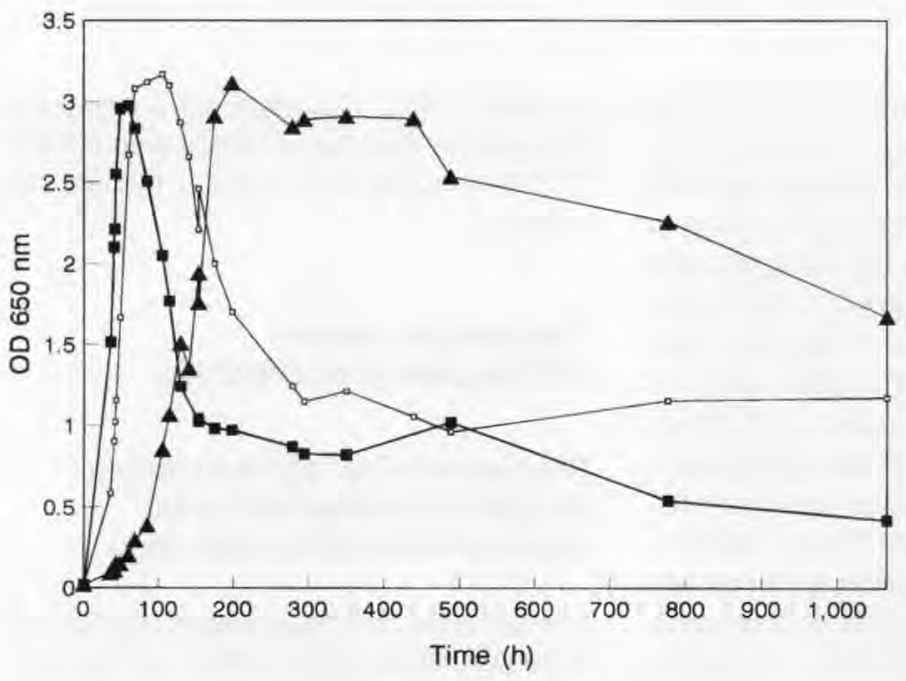

Fig 2. Growth of $P$ freudenreichii CNRZ 725 at different temperatures in YEL medium. Growth was followed by $O D_{650}$ for $1100 \mathrm{~h}$ of incubation at $15^{\circ} \mathrm{C}(\mathbf{\Delta})$, $24^{\circ} \mathrm{C}(\square)$ and $30^{\circ} \mathrm{C}(\mathbf{\square})$. Croissance de $\mathrm{P}$ freudenreichii CNRZ 725 en milieu YEL à différentes températures d'incubation. La croissance a été suivie par la mesure de la $D O_{650}$ sur une période de $1100 \mathrm{~h}$, pour 3 températures d'incubation: $15^{\circ} \mathrm{C}(\mathbf{\Delta})$, $24^{\circ} \mathrm{C}(\square)$ et $30^{\circ} \mathrm{C}(\square)$. 

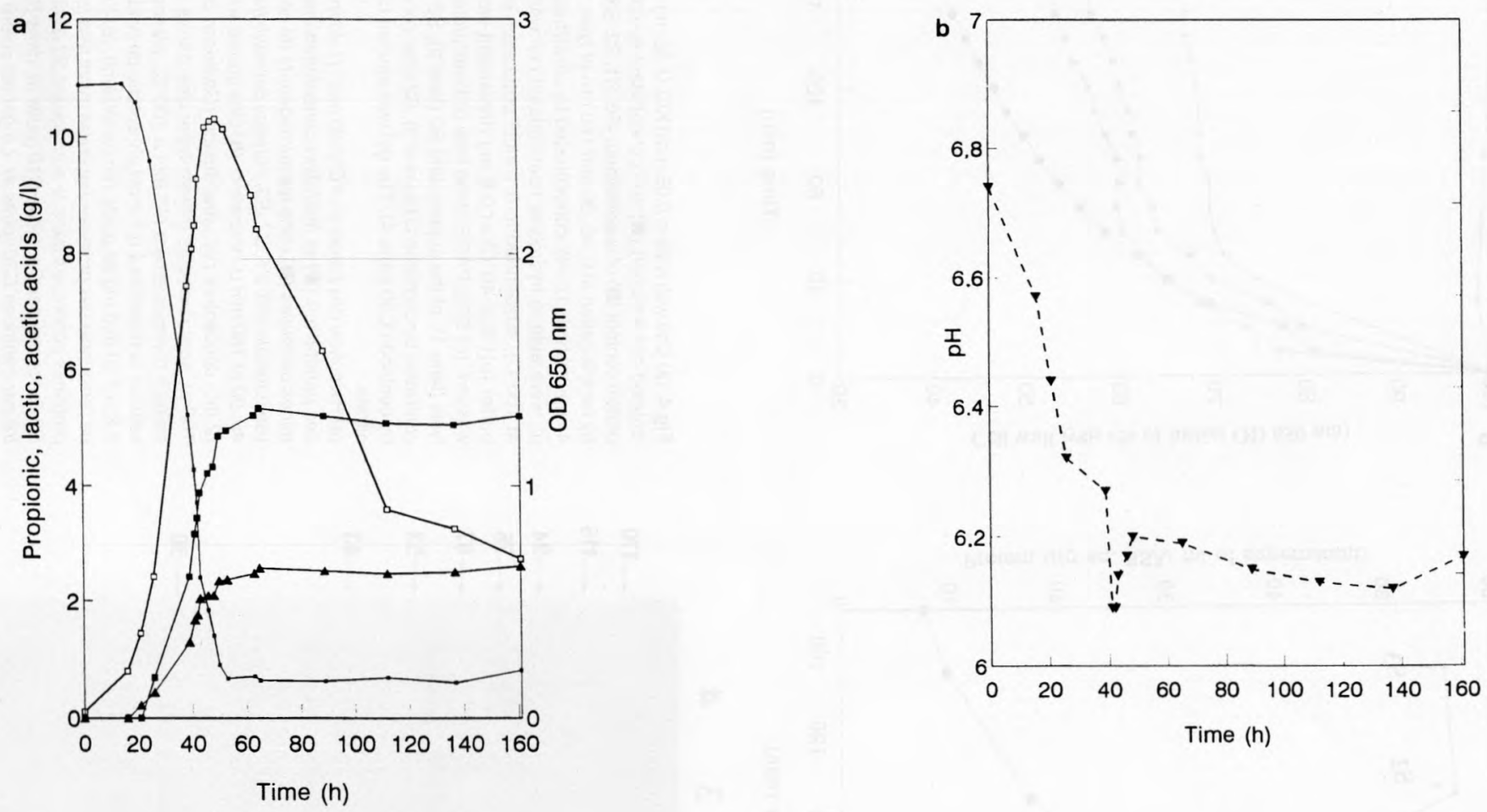

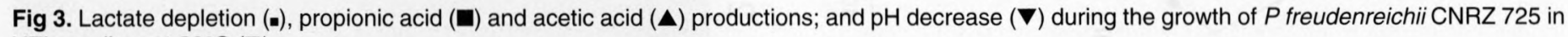
YEL medium at $30^{\circ} \mathrm{C}(\square)$.

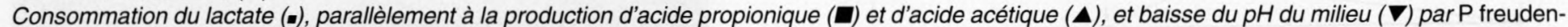
reichii CNRZ 725 au cours de sa croissance ( $\square$ ) sur YEL à $30^{\circ} \mathrm{C}$. 
a

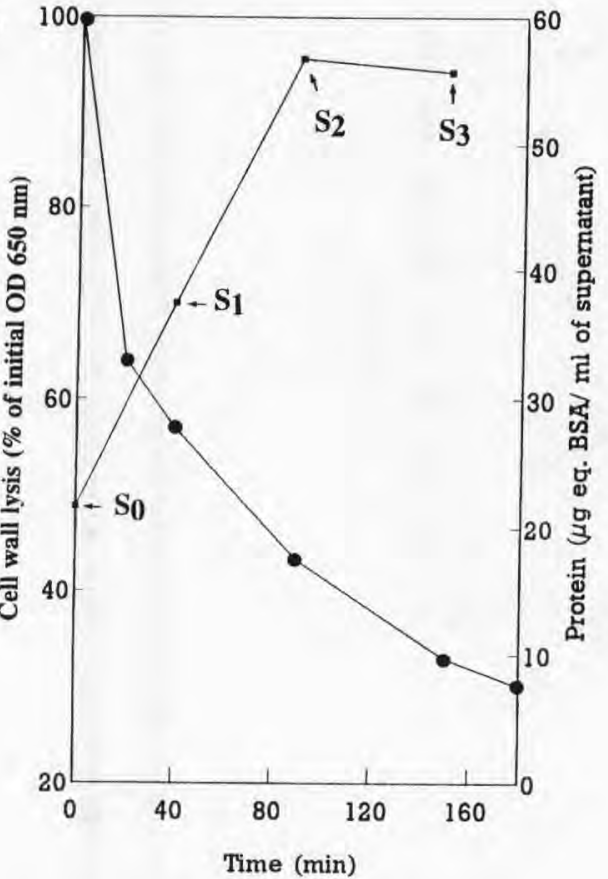

Time (min)

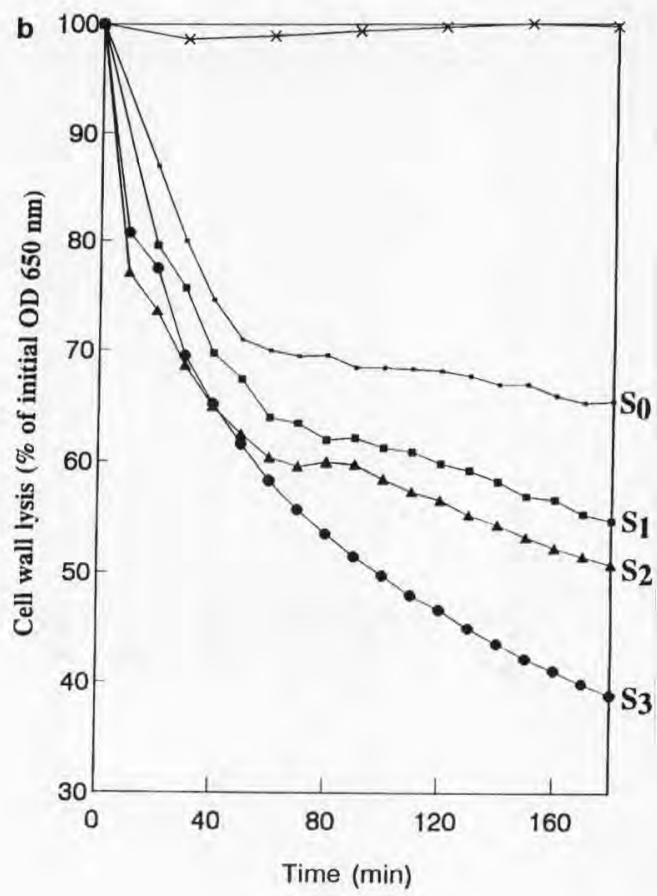

Fig 4. (a) Cell wall lysis in $0.05 \mathrm{~mol} / \mathrm{KCl}$ (1.46 mg dry weight isolated cell walls $/ \mathrm{ml})(-$ ) and concomitant evolution of the protein content (E) of supernatants (SO, S1, S2, S3) obtained by centrifugation at $0,40,90$ and 160 min of lysis. (b) These 4 supernatants $(2 \mathrm{ml})$, concentrated by ultrafiltration to 100 $\mu \mathrm{l}$, were able to hydrolyse heat-isolated cell walls (10 min at $100^{\circ} \mathrm{C}$ ), suspended in $0.1 \mathrm{~mol} / \mathrm{l}$ potassium phosphate buffer $\left(\mathrm{pH} 5.8 ; 40^{\circ} \mathrm{C}\right.$ ) at $0.6 \mathrm{mg}$ dry weight isolated cell walls $/ \mathrm{ml}$. (c) SDS-PAGE of the total cell wall proteins before lysis (lane 1), of the supernatant S2 (lane 2), S2 after concentration by centricon C10 (lane 3), S2 after concentration by centricon C30 (lane 4). The gel was stained using silver nitrate.

(a) Hydrolyse des parois en $\mathrm{KCl} 0,05$ mol/ $1,46 \mathrm{mg}$ de poids sec pariétal/ml) (-) libération concommittante des protéines pariétales (E) dans les surnageants de cette hydrolyse pariétale (SO, S1, S2, S3) obtenus par centrifugation à 0 , 40, 90 et 160 min d'incubation. (b) Ces quatre surnageants (2 ml), concentrés par ultrafiltration (Centricon-30) jusqu'à $100 \mu \mathrm{l}$, sont capables d'hydrolyser des parois isolées et traitées thermiquement ( $10 \mathrm{~min}$ à $100^{\circ} \mathrm{C}$ ), placées dans la solution tamponnée à 0,1 mol// phosphate de potassium $(\mathrm{pH}$ 5,$\left.8 ; 40^{\circ} \mathrm{C}\right)(0,6 \mathrm{mg}$ de poids sec pariétal/ml). (c) SDS-PAGE de l'ensemble des proteines pariétales avant lyse (puits 1) des protéines contenues dans le surnageant S2 (puits 2), dans S2 concentré par Centricon C10 (puits 3), dans S2 concentré par centricon C30 (puits 4). Le gel est coloré au nitrate d'argent. 
polysaccharides, since the neutral polysaccharide/protein (w/w) ratio was as high as 12 (table I). This ratio dramatically increased with cell walls from late exponential phase cells, even if the extent of cell wall lysis was comparable (table I). However, the lytic activity in the CE (per $\mathrm{mg}$ of protein) decreased when the neutral polysaccharide content increased (data not shown). According to table I, and in order to minimize the contamination by neutral polysaccharides, the CE was always prepared by the lysis of cell walls from cells harvested at an ${ } D_{650}$ below 0.5 .

\section{Preparation of heated whole cells as substrate for the quantification of the lytic activities}

Ideally, the detection and quantification of lytic activities should be made on whole cells devoid of endogenous autolytic activity. Whole cells of strain CNRZ 725 were harvested in the early exponential growth phase $\left(\mathrm{OD}_{650}<0.5\right)$ and submitted to several heating conditions or to a drastic formic acid treatment. Similarly, lyophilized whole cells of Micrococcus luteus were submitted to some of these treatments. Thereafter, they were suspended in $0.1 \mathrm{~mol} / \mathrm{l}$ potassium phosphate buffer $\left(\mathrm{pH} \mathrm{5.8)}\right.$ at $40^{\circ} \mathrm{C}$, in order to verify, by the stability of the $O D_{650}$ during a 3-h incubation, the inactivation of their own autolysins, which was the first condition for being a convenient substrate. The second condition was the susceptibility to the lytic activity of the CE (table II). The $M$ luteus cells were not stable at all in the conditions of incubation used, except after the formic acid treatment, but the cells obtained in this case were not lysed by the CE. In contrast, 3 of the 4 heat treatments applied to whole cells of strain CNRZ 725 as well as the formic acid treatment led to stable cellular suspensions, which could be all lysed by the addition of some CE (table II). The treatment at $121^{\circ} \mathrm{C}$ for $15 \mathrm{~min}$ was retained since it could be made easily by autoclaving the cells and thus ensured, because of the sterility, a good preservation of the cells after treatment. In conclusion, autoclaved whole cells were used as substrate in the conditions described in detail in the Materials and Methods section for the quantification of the lytic activity of any crude

Table 1. Obtention of cell walls from cells harvested at different growth phases: extent of cell wall lysis and neutral polysaccharide to protein ratio (w/w) (NP/P) of the crude extract (CE) obtained in each case.

Préparation de parois à partir de cellules récoltées à différents stades de culture; hydrolyse des parois isolées et rapport entre les polysaccharides neutres et les protéines (p/p) (NP/P) contenus dans l'extrait brut (CE), obtenu dans chaque cas.

\begin{tabular}{lccc}
\hline Whole cells & $\begin{array}{c}\text { Isolated cell walls } \\
\text { CE }\end{array}$ & \multicolumn{2}{c}{ CE } \\
\cline { 2 - 4 } $\begin{array}{l}O D_{650} n m \\
\text { of harvesting }\end{array}$ & $\begin{array}{c}\text { Extent of lysis * } \\
(\%)\end{array}$ & $\begin{array}{c}\text { Protein content } \\
(\mu g \text { eq } B S A / m /)\end{array}$ & $\begin{array}{c}\text { NP/P ratio } \\
(w / w)\end{array}$ \\
\hline 0.3 & 71 & 488 & 12 \\
0.53 & 76 & 780 & 11 \\
1 & 66 & 1295 & 41 \\
\hline
\end{tabular}

\footnotetext{
* Percent decrease of $\mathrm{OD}_{650}$ after $3 \mathrm{~h}$ of incubation.

* Pourcentage de diminution de la $\mathrm{DO}_{650}$ après $3 \mathrm{~h}$ d'incubation.
} 
Table II. Assays of several substrates for quantifying by spectrophotometry the lytic activity of the crude extract (CE)*.

Recherche d'un substrat pour la quantification de l'activité lytique de l'extrait brut (CE) par spectrophotométrie.

$\begin{array}{cc}\text { Substrate } & \text { Loss of } O D_{650} n m \\ \text { after } 3 \text { h incubation }(\%) & \text { Sensibility } \\ \text { without } C E & \text { to } C E^{a}\end{array}$

Whole cells of CNRZ 725

Whole cells of Micrococcus luteus
$15 \mathrm{~min}$ at $100^{\circ} \mathrm{C}$

$30 \mathrm{~min}$ at $100^{\circ} \mathrm{C}$

$60 \mathrm{~min}$ at $100^{\circ} \mathrm{C}$

$15 \mathrm{~min}$ at $121^{\circ} \mathrm{C}$

formic acid $\left(1 \mathrm{~N}, 30 \mathrm{~min}, 4^{\circ} \mathrm{C}\right)$

without treatment

$30 \mathrm{~min}$ at $100^{\circ} \mathrm{C}$

formic acid $\left(1 \mathrm{~N}, 30 \mathrm{~min}, 4^{\circ} \mathrm{C}\right)$

$\begin{array}{cc}10 & + \\ 3 & + \\ 2.5 & + \\ 1-3 & + \\ 1 & +\end{array}$

40

$45-50$

4

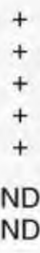

ND

\footnotetext{
* The substrates were suspended in $0.1 \mathrm{~mol} / \mathrm{l}$ potassium phosphate buffer $\left(\mathrm{pH} 5.8,40^{\circ} \mathrm{C}\right)$.

$a_{+}$, loss of $O_{650} \mathrm{~nm}>35 \%$ after a $3 \mathrm{~h}$ incubation at $40^{\circ} \mathrm{C} ;-:$ no significant loss of $\mathrm{OD}_{650}$; ND: not determined.

* Les substrats étaient placés dans une solution de 0,1 mol/l phosphate de potassium ( $\mathrm{pH} 5,8 ; 40^{\circ} \mathrm{C}$ ).

$a_{+}$, perte de $\mathrm{DO}_{650} \mathrm{~nm}>35 \%$ après une incubation de $3 \mathrm{~h}$ à $40^{\circ} \mathrm{C}$; - : pas de perte significative de $\mathrm{DO} 650^{;} \mathrm{ND}$ : non déterminé.
}

or partially purified extract. The main parameter used was the initial rate of the $\mathrm{OD}_{650}$ decrease (over a $15 \mathrm{~min}$ period) induced by a $100 \mu \mathrm{l}$ sample of extract. One UA was defined as the quantity of enzymatic activity leading to a decrease of $0.001 \mathrm{uOD} / \mathrm{min}$. As shown, for example, in table III, $100 \mu \mathrm{l}$ of CE contained 11.7 UA.

Nevertheless, it was not possible by this way to know whether the activity was due to one or several autolysins. For this reason, we tried to apply to dairy propionibacteria a method described by Potvin et al (1988) and Leclerc and Asselin (1989) for visualizing lytic activities in the polyacrylamide gel after denaturing electrophoresis and this is discussed in the next section.

\section{Qualitative analysis of the autolysins by renaturing electrophoresis}

In the method described by Potvin et al (1988), whole cells or cell walls of M luteus, or of the species considered, are included in the polyacrylamide network, and lytic activities are observed as clear bands in the turbid gel after incubation in a $1 \%$ Triton $\mathrm{X}$ 100 containing buffer. In the present work, autoclaved whole cells of strain CNRZ 725 were included in the acrylamide network. A CE sample was mixed with an equivalent volume of Laemmli buffer, heated for $2 \mathrm{~min}$ at $100^{\circ} \mathrm{C}$ and $20 \mu \mathrm{l}$ aliquote was loaded on the gel. After electrophoresis, the gel was soaked in distilled water for $30 \mathrm{~min}$ and then incubated under stirring in $0.1 \mathrm{~mol} / \mathrm{l}$ phosphate buffer, $\mathrm{pH} 5.8$, at $40^{\circ} \mathrm{C}$ (optimal conditions previously defined for this autolytic system) and containing $1 \%(\mathrm{w} / \mathrm{v})$ Triton $\mathrm{X}$ 100. After $3 \mathrm{~h}$, at least 8 lytic activities were observed (fig 5, lane 1). The most intense had an apparent molecular mass of 121 $\mathrm{kDa} ; 6$ other activities were visualized between 80 and $118 \mathrm{kDa}(81,87,92,100$, 109 and $118 \mathrm{kDa}$ ); the last activity at an apparent molecular mass of $34 \mathrm{kDa}$ was 
Table III. Protein and neutral polysaccharide contents, and lytic activity of the crude extract (CE) of autolysins and of the different fractions obtained after an ammonium sulfate precipitation.

Teneur en protéines et polysaccharides neutres, et activité lytique de l'extrait brut d'autolysines (CE), et des différentes fractions obtenues après une précipitation au sulfate d'ammonium.

\begin{tabular}{|c|c|c|c|c|}
\hline Fractions & $\begin{array}{c}\text { Proteins } \\
\text { (mg eq BSA/ml) }\end{array}$ & $\begin{array}{c}\text { Neutral } \\
\text { polysaccharides } \\
\text { (mg eq glucose } / m l \text { ) }\end{array}$ & $\begin{array}{l}\text { NP/P } \\
\text { ratio* } \\
(w / w)\end{array}$ & $\begin{array}{c}U A \\
(0-15 \mathrm{~min}) \\
(100 \mu \mathrm{l})\end{array}$ \\
\hline
\end{tabular}

$\begin{array}{lrrrrr}\text { CE } & 1.92 & 21 & 11 & 11.7 & 61 \\ \text { P50 } & 1.60 & 2.4 & 1.5 & 12.1 & 76 \\ \text { S50 } & 0.80 & 20.6 & 26 & 11.8 & 148 \\ \text { P70 } & 0.41 & 1.5 & 3.7 & 10.5 & 256 \\ \text { S70 } & 0.21 & 13.5 & 64 & 1.3 & 62\end{array}$

* NP/P ratio: neutral polysaccharide/protein ratio. NB: the isolated cell walls of CNRZ 725 used for the obtention of $\mathrm{CE}$, contained $380 \mu \mathrm{g}$ eq BSA of proteins $/ \mathrm{mg}$ walls dry weight and $560 \mu \mathrm{g}$ eq glucose of neutral polysaccharides/mg walls dry weight; then, the NP/P ratio was about 1.5 .

* NP/P ratio : rapport polysaccharides neutres/protéines. NB: les parois isolées de CNRZ 725 utilisées pour l'obtention de CE, contiennent $380 \mu \mathrm{g}$ eq $\mathrm{SAB}$ de protéines $/ \mathrm{mg}$ de poids sec pariétal et $560 \mu \mathrm{g}$ eq glucose de polysaccharides neutres/mg de poids sec de parois ; ainsi, le rapport NP/P est de 1,5 pour les parois isolées.
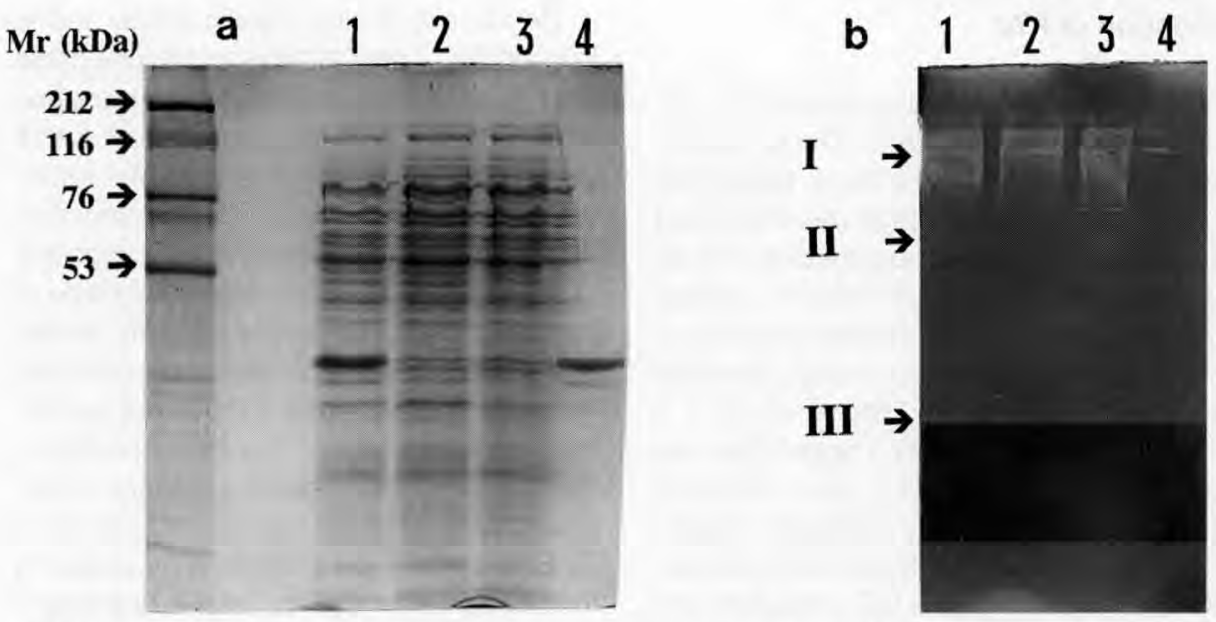

Fig 5. (a) Protein profiles and (b) profiles after renaturing SDS-PAGE of the following extracts: lane 1: $\mathrm{CE}$; lane 2: pellet sulfate ammonium precipitation of CE at $70 \%$ (P70); lane 3: supernatant of CE sulfate ammonium precipitation at $70 \%$ (S70); lane 4: pellet sulfate ammonium precipitation of $\mathrm{CE}$ at $50 \%$ (P50).(Renaturation buffer: $0.1 \mathrm{~mol} / \mathrm{l}$ potassium phosphate, $\mathrm{pH} 5.8$ with $1 \%(\mathrm{w} / \mathrm{v})$ Triton $\mathrm{X}-100$; $40^{\circ} \mathrm{C}$ ). (Lytic activities: I: $120 \mathrm{kDa}$; II: 81 to $118 \mathrm{kDa}$; III: $34 \mathrm{kDa}$ ).

Profils protéiques (a) et profils d'activité (b) après renaturation des autolysines en tampon de 0,1 mol/ de phosphate de potassium, $\mathrm{pH} 5,8$, additionné de $1 \%$ de Triton $X-100$, à $40^{\circ} \mathrm{C}$. Les extraits enzymatiques sont les suivants : puits 1 : extrait brut (CE) ; puits 2: culot après précipitation du CE à $70 \%$ de sulfate d'ammonium ( $P 70)$; puits 3 : surnageant après précipitation du CE à $70 \%$ de sulfate d'ammonium (S70); puits 4 : culot après précipitation du CE à $50 \%$ de sulfate d'ammonium (P50); (activités lytiques : I: $120 \mathrm{kDa}$; II: 81-118 kDa ; III: $34 \mathrm{kDa}$ ). 
weak, and not completely translucent. A quantity as low as $4 \mu \mathrm{g}$ protein (corresponding to 1 UA) in the CE sample loaded was sufficient to observe all these lytic activities, indicating that the method is sensitive.

It could be noted that other substrates have been tentatively included in the gel as i) whole cells of autoclaved M luteus, but no lytic bands at all were obtained; ii) heattreated cell walls of CNRZ 725 , and the profile obtained was exactly the same as with autoclaved whole cells (data not shown). In order to determine which lytic activity detected on the gel corresponded to the $\mathrm{N}$ acetylglucosaminidase activity mainly involved in the autolysis of strain CNRZ 725 (Lemée et al, 1994b), the purification was undertaken.

\section{Ammonium sulfate precipitation of autolysin(s) from the CE: obtention of P70}

The CE was precipitated by ammonium sulfate successively at 50 and $70 \%$ of saturation $(w / v)$ leading to 4 fractions: pellet P50 and supernatant $\mathrm{S} 50$, which was then used to obtain pellet $\mathrm{P} 70$ and supernatant $S 70$. As summarized in table III, all fractions, except $\mathrm{S70}$, contained significant amounts of lytic activity (about $10 \cup A$ ). Surprisingly, the total activity of P50 and S50 together (12.1+ $11.8=23.9$ UA) was 2 -fold higher than the initial activity of CE (11.7 UA). A similar observation has been made by Foster (1993) in the course of the ammonium sulfate precipitation from a CE containing the endolysin of a bacteriophage infecting $B$ subtilis. On the other hand, the sum of the S70 (1.3 UA) and P70 (10.5 UA) activities was coherent with the S50 (11.8 UA) activity. It was also noted that the neutral polysaccharides initially present in the CE remained mainly soluble in the final supernatant $\mathrm{S} 70$, and the ammonium sulfate precipitation was thus an easy way for eliminating them, at least partially. P70 was the sample showing the highest specific activity, with a 4-fold increase compared to the initial CE (256/61). Fractions CE, P50, P70 and S70 were analyzed by SDS-PAGE (fig 5a) and by renaturing gel electrophoresis (fig $5 b)$. The protein profiles of CE, P50 and P70 were very similar, indicating that almost all the proteins precipitated by the addition of ammonium sulfate at the concentrations used. The only exception was seemingly a predominant protein of about $30 \mathrm{kDa}$, which clearly remained in $\mathrm{S} 70$ (fig 5a). In terms of lytic activities, the 8 lytic bands found in CE were also observed in the P50 and the P70 profiles (fig 5b), In the $S 70$ sample, no lytic bands could be observed except a residual weak band at $121 \mathrm{kDa}$, and this observation was coherent with its low total activity (1.3 UA). The low protein content of S70 $(0.21 \mathrm{mg} / \mathrm{ml}$ ) and its protein profile (fig $5 \mathrm{a}$, lane 4) were also in agreement.

Because of its high specific activity and its low content of neutral polysaccharides (table III), P70 was chosen for the following steps of purification (next paragraph). It was also used to assay several media for the renaturation of the 8 lytic activities detected after denaturing gel electrophoresis, especially in order to find potential inhibitors of some of these activities. The results are summarized in table IV. The first observation was that the presence of Triton X-100 was necessary for renaturation. The best conditions were to incubate the gel in i) $0.1 \mathrm{~mol} / / \mathrm{phos}$ phate buffer $\mathrm{pH} 5.8$ or ii) $\mathrm{KCl} 100 \mathrm{mmol} / \mathrm{l}$ or iii) Emmental juice (obtained by pressing the cheese after the end of the ripening in warm room), all containing $1 \%$ Triton $X-100$ $(w / v)$. This was not surprising with media i) and ii) since they were previously described as inducing efficiently the autolytic system of the strain (Lemee et al, 1994b). The fact that the renaturation and the lytic activities of all the bands occurred in Emmental juice was an exciting observation, of practical interest. Finally, the divalent cations $\mathrm{Mg}, \mathrm{Cu}$ and $\mathrm{Zn}$ were able to inhibit the renaturation 


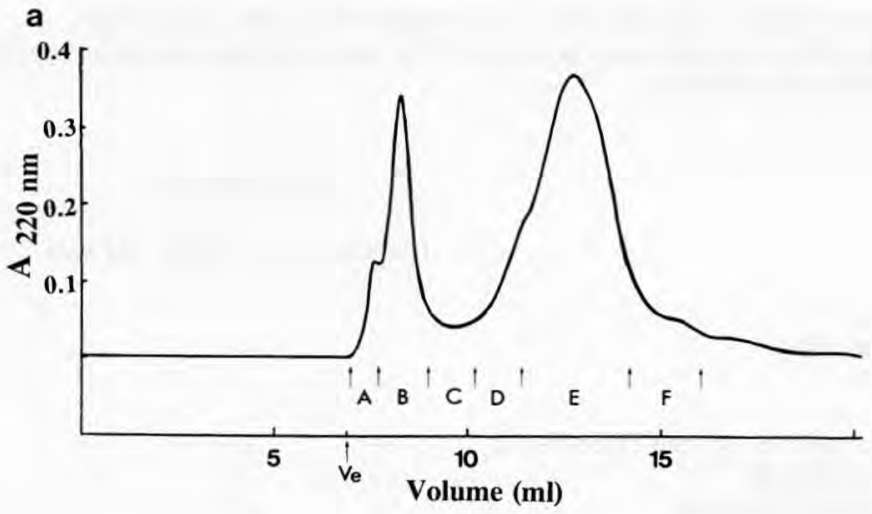

Fig 6. Elution profile (a) of P70 extract on gel permeation chromatography (Superose 12) $(50 \mathrm{mmol} / /$ potassium phosphate buffer, $\mathrm{pH} 5.8$ containing $50 \mathrm{mmol} / \mathrm{KCl}$ ) and (b) renaturing SDS-PAGE profiles of the fractions obtained: lanes 1: CE; 2: A; 3: B; 4: C; 5 : D; 6 : E; 7 : F (Renaturation buffer: $0.1 \mathrm{~mol} / \mathrm{l}$ potassium phosphate buffer pH 5.8 - Triton X-100); (Lytic activities: I: $120 \mathrm{kDa}$; II: 81 to $118 \mathrm{kDa}$; III: $34 \mathrm{kDa}$ ).

Profil d'élution de l'extrait P70 (a) en chromatographie de gel filtration (Superose 12), en tampon de phosphate de potassium $(50 \mathrm{mmol}, \mathrm{pH} 5,8)$ à $50 \mathrm{mmol}$ de $\mathrm{KCl}$ et (b) profils d'activité des différentes fractions obtenues : 1) $C E$; 2) $A$; 3) $B$; 4) $C$; 5) $D$; 6) $E$; 7) $F$. (Renaturation de l'activité dans 0,1 mol/l phosphate de potassium à $\mathrm{pH} 5,8$ - Triton $X-100)$; (activités lytiques : I: $120 \mathrm{kDa}$; II: 81-118 kDa; III: $34 \mathrm{kDa})$.

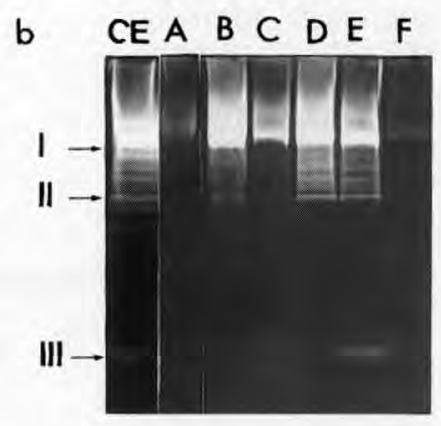

and/or the enzymatic activity of all or some of the lytic activities of P70, depending on the concentrations used.

\section{Gel permeation and anion exchange chromatography of P70}

P70 was loaded on a gel permeation column. Figure 6 shows the elution profile obtained as well as the analysis by renaturing gel electrophoresis of the 6 fractions collected $(A, B, C, D, E, F)$. The fractions were concentrated to an identical volume of $3 \mathrm{ml}$ by using Centricon-3 (cutoff 3000 ) before analysis. The 8 lytic activities were not really separated by this gel permeation chromatography. Several conditions of elution were tested unsuccessfully for improving the separation: molarity of the phosphate buffer (10 to $50 \mathrm{mmol} / \mathrm{l}), \mathrm{pH}(5.8,6.0,6.5)$, addition of 0.15 to $2 \mathrm{~mol} / \mathrm{l} \mathrm{KCl}$ in the phosphate buffer and reduction of the elution rate from 0.5 to $0.3 \mathrm{ml} / \mathrm{min}$. Nevertheless, fractions C and $\mathrm{E}$ were interesting because: $i$ ) the fraction $\mathrm{C}$ contained seemingly only the $121 \mathrm{kDa}$ activity; ii) the fraction $\mathrm{E}$ contained all the lytic activities, and moreover the lytic activity at $34 \mathrm{kDa}$ was more intense than in P70.

Fraction $\mathrm{C}(40 \mu \mathrm{g}$ eq BSA) was added to $1.5 \mathrm{mg}$ of heated cell walls $(10 \mathrm{~min}$, $100^{\circ} \mathrm{C}$ ), and induced a decrease of about $21 \%$ of the $\mathrm{OD}_{650}$ of the cell wall suspension after $6 \mathrm{~h}$ in $0.05 \mathrm{~mol} / / \mathrm{KCl}$ at $40^{\circ} \mathrm{C}$. The concomitant apparition of glucosaminitol was 
Table IV. Renaturation in various media of the lytic activities of fraction P70, after SDS-PAGE. Renaturation des activités lytiques contenues dans la fraction $\mathrm{C70}$, dans diverses solutions, après une électrophorèse en conditions dénaturantes.

Solution of renaturation

Lytic activities

$121 \mathrm{kDa} \quad 81-118 \mathrm{kDa} \quad 34 \mathrm{kDa}$

Distilled water without Triton X-100

Distilled water

Potassium phosphate $0.1 \mathrm{~mol} / / \mathrm{pH} 5.8$, without Triton $\mathrm{X}-100$

Potassium phosphate $0.1 \mathrm{~mol} / / \mathrm{pH} 5.8$

Potassium phophate $25 \mathrm{mmol} / / \mathrm{pH} 5.8$ (KPB)

$\mathrm{KPB}+\mathrm{MgSO}_{4} 10 \mathrm{mmol} / \mathrm{l}$

$\mathrm{KPB}+\mathrm{MgSO}_{4} 100 \mathrm{mmol} / \mathrm{l}$

$\mathrm{KPB}+\mathrm{MgCl}_{2} 10 \mathrm{mmol} / \mathrm{I}$

$\mathrm{KPB}+\mathrm{MgCl}_{2} 100 \mathrm{mmol} / \mathrm{I}$

$\mathrm{KPB}+\mathrm{CuSO}_{4} 10 \mathrm{mmol} / \mathrm{I}$

$\mathrm{KPB}+\mathrm{CuSO}_{4} 100 \mathrm{mmol} / \mathrm{I}$

$\mathrm{KPB}+\mathrm{CuCl}_{2} 10 \mathrm{mmol} / \mathrm{l}$

$\mathrm{KPB}+\mathrm{CuCl}_{2} 100 \mathrm{mmol} / \mathrm{l}$

$\mathrm{KPB}+\mathrm{ZnCl}_{2} 10 \mathrm{mmol} / \mathrm{I}$

$\mathrm{KPB}+\mathrm{ZnCl}_{2} 100 \mathrm{mmol} / \mathrm{l}$

Potassium phoshate $25 \mathrm{mmol} / / \mathrm{pH} 8.0$

Tris-HCl $0.1 \mathrm{~mol} / / \mathrm{pH} 8.0$

$\mathrm{KCl} 100 \mathrm{mmol} / \mathrm{l}$

Emmental juice $(\mathrm{pH} 5.7)^{*}$

$\begin{array}{ccc}- & - & - \\ - & - & - \\ +1- & +1- & - \\ ++ & ++ & + \\ + & +++ & + \\ ++ & ++ & + \\ ++ & ++ & + \\ ++ & ++ & +1- \\ ++ & ++ & - \\ ++ & - & - \\ - & - & - \\ + & - & - \\ - & - & - \\ + & +- & - \\ + & - & - \\ ++ & ++ & - \\ ++ & + \\ ++ & + & - \\ +++ & +++ & ++ \\ +++ & +++ & ++\end{array}$

All the solutions contained $1 \%(\mathrm{w} / \mathrm{v})$ of Triton X-100 (except if indicated otherwise in the table). The substrate included in the gel was autoclaved whole cells of $P$ freudenreichii CNRZ 725. * The Emmental juice obtained from a 32-d ripened Emmental according to the Morris et al (1988) method, contained $30 \mathrm{~g} / \mathrm{llactate}, 0.2 \mathrm{~mol} / \mathrm{l} \mathrm{Ca} \mathrm{Ca}^{2+}, 0.3$ $\mathrm{mol} / \mathrm{l} \mathrm{Na}+, 0.2 \mathrm{~mol} / / \mathrm{Cl}^{-}, 0.06 \mathrm{~mol} / / \mathrm{I} \mathrm{K}^{+}, 0.03 \mathrm{~mol} / \mathrm{I} \mathrm{Mg}^{2+}$ (Salvat-Brunaud et al, 1995).

Tous les milieux d'incubation contiennent $1 \%(p / v)$ de Triton $X-100$ (sauf indication contraire dans le tableau). Substrat inclus dans le gel : cellules entières de P freudenreichii CNRZ 725 autoclavées. *le jus d'emmental obtenu à partir d'un emmental affiné de 32 jours selon la méthode de Morris et al (1988), renferme entre autres 30 g/l de lactate, 0,2 mol// $\mathrm{Ca}^{2+}, 0,3 \mathrm{~mol} / \mathrm{l} \mathrm{Na}^{+}, 0,2 \mathrm{~mol} / \mathrm{l} \mathrm{Cl}, 0,06 \mathrm{~mol} / \mathrm{K} \mathrm{K}^{+}, 0,03 \mathrm{~mol} / \mathrm{Mg} \mathrm{Mg}^{2+}$ (Salvat-Brunaud et al, 1995).

detected (data not shown), indicating that this $121 \mathrm{kDa}$ activity might be the $\mathrm{N}$-acetylglucosaminidase mainly involved in the autolysis of strain CNRZ 725 (Lemée et al, $1994 b)$. Furthermore, fraction $\mathrm{E}(270 \mu \mathrm{g}$ eq BSA) was loaded on an anion exchange column (Mono $Q$ ) and again the lytic activities were not separated, and were mainly excluded all together (fraction 1) (fig 7).

\section{Extraction of autolysins from whole cells}

The preliminary attempts of purification described earlier revealed the complexity of separating the lytic activities present in the CE. In addition, these assays suffered from the fact that the CE was a starting material tedious to obtain, thus limiting the number of chromatography steps which 
could be realized. For this reason, we have tried to find a direct way to extract autolysins from whole cells of strain CNRZ 725. In the literature, autolysins have been extracted
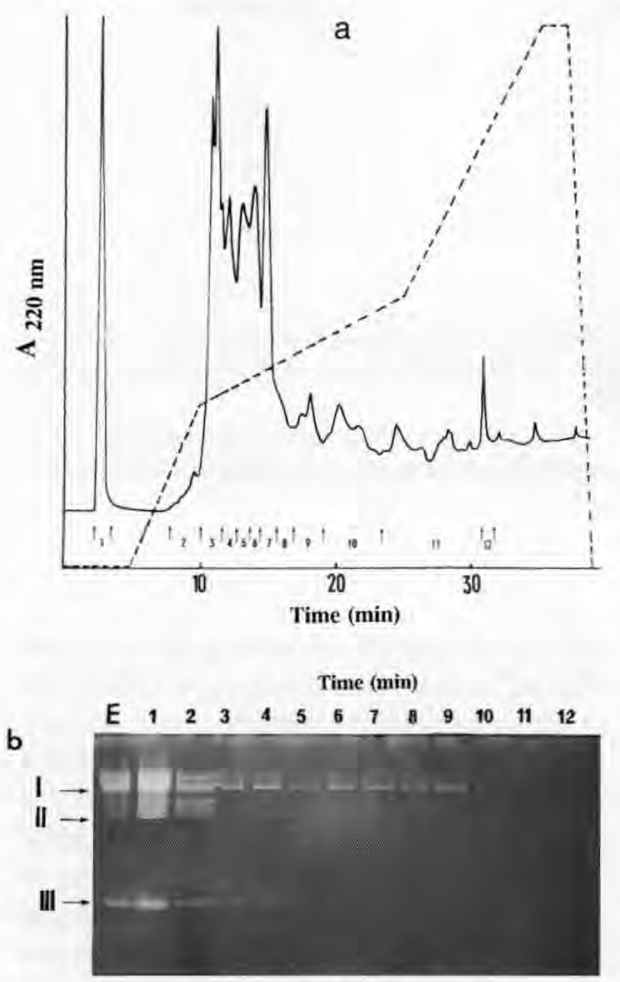

Fig 7. Elution profile of the fraction $E$, obtained in figure 6 by gel permeation, on (a) anion exchanger chromatography (Mono $Q$ ) and (b) renaturing SDS-PAGE profiles of the fractions obtained: lane 1: $E$ fraction; lanes 2 to 13: the 12 pooled fractions obtained by chromatography, called 1 to 12 . (Renaturation buffer: $0.1 \mathrm{~mol} / \mathrm{l}$ potassium phosphate buffer $\mathrm{pH} 5.8$ - Triton $X$ 100); (Lytic activities: I: $120 \mathrm{kDa}$; II: 81 to 118 $\mathrm{kDa}$; III: $34 \mathrm{kDa}$ ).

Profil d'élution de l'extrait $E$ (obtenu par gel filtration, fig 6) en chromatographie échangeuse d'anions (a) et profils d'activité des différentes fractions obtenues $(b)$ : puits 1 : fraction $E$; puits 2 à 13: 12 fractions obtenues par chromatographie, numérotées de 1 à 12 . (Renaturation de l'activité dans $0,1 \mathrm{~mol} / \mathrm{l}$ phosphate de potassium à $\mathrm{pH}$ 5,8-Triton $X-100$ ); (activités lytiques : I: $120 \mathrm{kDa}$; II: 81 - $118 \mathrm{kDa}$; III: $34 \mathrm{kDa}$ ). directly from whole cells by anionic detergent (Sugai et al, 1990; Foster, 1992; Valence and Lortal, 1995), $5 \mathrm{~mol} / \mathrm{l} \mathrm{NaCl}$ (Brown, 1972) or LiCl ( 0.5 to $5 \mathrm{~mol} / \mathrm{l}$ ) (Pooley et al, 1970; Valence and Lortal, 1995).

As the autolysins of strain CNRZ 725 can be observed ( 8 lytic activities) after denaturing gel electrophoresis, their resistance toward SDS can be presumed. Washed exponential-phase cells of this strain $(5 \mathrm{mg}$ dry weight) were suspended either in $1 \%$ $\mathrm{SDS}$ or in $1 \mathrm{~mol} / \mathrm{L} \mathrm{LiCl}$ (as described in detail in the Materials and Methods section). After extraction and centrifugation, the soluble lytic activity was qualitatively analyzed by renaturing SDS-PAGE and quantified by the spectrophotometric assay on autoclaved whole cells of strain CNRZ 725. The results (table V) indicated that the $1 \mathrm{~mol} / / \mathrm{LiCl}$ treatment was an efficient way to extract autolysin from whole cells. Moreover, the contamination of the $\mathrm{LiCl}$ extract by neutral polysaccharides was very low (8-fold lower than in CE).

\section{DISCUSSION}

The autolytic activity of the dairy propionibacteria is dependent on the strain and even seemingly on the species (the strains most prone to autolysis were all of the species $P$ freudenreichii) (Langsrud, 1974; Lemée et al, 1994a). In order to see if the screening previously developed to detect "autolytic strains" by suspending them in phosphate buffer (Lemée et al, 1994a) could be correlated with their spontaneous behavior in culture medium, the growth of 7 strains was followed in this work in lactate broth at $30^{\circ} \mathrm{C}$ during $1100 \mathrm{~h}$. The strains most prone to autolysis in buffer were again those showing the highest rate and extent of spontaneous autolysis in the growth medium. Even if the growth of a greater number of strains should be followed up before any definitive conclusion, the present work supported the idea 
Table V. Extraction of autolysins from whole cells by $1 \%$ SDS and $1 \mathrm{~mol} / / \mathrm{LiCl}$ : Iytic activity, protein and neutral polysaccharide contents of the autolysin extracts.

Extraction des autolysines à partir de cellules entières par du SDS $1 \%$ et du LiCl 1 molll : activité Iytique, teneur en protéines et polysaccharides neutres de ces extraits d'autolysines.

SDS extract

14.5

2.2

NDa

UA $(500 \mu \mathrm{l})$

Protein ( $\mu \mathrm{g}$ eq $\mathrm{BSA} / \mathrm{ml}$ )

Specific activity

NP/P ratio ${ }^{b}(w / w)$
$\mathrm{LiCl}$ extract

6.3

341

37

1.4

The extent of lysis was expressed as the percent decrease of $\mathrm{OD}_{650}$ after $3 \mathrm{~h}$ of incubation. a ND: not determined, because of the interference of the SDS with the Bradford procedure; ${ }^{b}$ NP/P ratio: neutral polysaccharide/protein ratio $(\mathrm{w} / \mathrm{w})$.

Le taux de lyse est exprimé comme étant le pourcentage de diminution de la $D_{650}$ après $3 \mathrm{~h}$ d'incubation. a $\mathrm{ND}$, non déterminé, du fait de la présence de SDS qui est incompatible avec la méthode de Bradford; ${ }^{b}$ NP/P ratio : rapport polysaccharides neutres/protéines $(p / p)$.

of the validity of the screening in buffer applied by Lemée et al (1994a) over 57 strains. This obvious strain dependence of autolysis in dairy propionibacteria is of practical value for the choice of cheese starters, but also leads to an interesting fundamental question. It suggests the presence of different and specific autolytic systems for each strain and/or different levels of regulation. According to the suggestions of Jolliffe et al (1981) and Kemper and Doyle (1993), the apparent resistance of the cells to autolysis during normal growth reflects the strong control of autolysins by energized membrane. Effectively, the cell life principally depended on the intracellular $\mathrm{pH}$ (buffering capacity and ionic force of the cytoplasm), and on the turgor pressure which are directly linked to the $\mathrm{pH}$ and content of the environmental medium (Ingraham, 1987). In this work, the spontaneous autolysis of $P$ freudenreichii CNRZ 725 after maximal growth in YEL medium occurred at $\mathrm{pH} 6.2$ when the lactate was depleted and at a compatible temperature $\left(15-24-30^{\circ} \mathrm{C}\right)$. These conditions (in terms of absence of nutrient,
$\mathrm{pH}$ and temperature) were close to those that led to extensive autolysis of CNRZ 725 in buffered solution (Lemée et al, 1994b). The hypothesis from which the $\mathrm{pH}$ of the growth medium had an effect upon the induction of the whole cell autolysis of CNRZ 725 was in agreement with the results of Langsrud (1974). He showed that the initial $\mathrm{pH}$ of the growth medium influenced the release of the intracellular proline iminopeptidase by spontaneous autolysis of $P$ freudenreichii P59 cells. In experimental Swiss-type cheese, Kurtz et al (1959) observed relationships between the initial $\mathrm{pH}$ off the press and the growth curve (and in particular the loss of viability after maximal growth) of dairy propionibacteria (Propionibacterium freudenreichii subsp shermanii). $\mathrm{A} \mathrm{pH}$ off the press of about 5.25 accelerated the starting point of the loss of viability in the curd, compared to an initial $\mathrm{pH}$ of about 5.37 and 5.82 .

Nevertheless, if $\mathrm{pH}$ decrease and nutrient depletion are undoubtedly key factors of autolysis induction, it must be emphasized that autolyses have been observed even in 
the presence of lactate (as, eg, when the temperature of growth is suddenly increased from 30 to $40^{\circ} \mathrm{C}$ during the exponential phase; or when exponential whole cells are suspended in Emmental juice obtained by pressing the cheese before the warm room) (data not shown). Further experiments must be undertaken to understand precisely the molecular mechanism of this induction. Nevertheless, it could be underlined that the conditions leading to autolysis of CNRZ 725 cells were similar in terms of $\mathrm{pH}$ and salinity (Lemée et al, 1994b) to those of the aqueous phase of Emmental during ripening (SalvatBrunaud et al, 1995). Moreover, this work showed that the Emmental juice allowed the expression of the autolysins of strain CNRZ 725. In spite of the high optimal temperature $\left(40^{\circ} \mathrm{C}\right)$ of this autolytic system, we showed that CNRZ 725 cells were able to autolyse in growth medium at 15 or $24^{\circ} \mathrm{C}$ (temperature of Swiss-type cheese ripening). Thus, this work demonstrated that the aqueous phase of Swiss-type cheeses would be adequate to promote the autolysis of propionibacteria at the ripening temperature.

The autolysins from a dairy propionibacteria strain were isolated here for the first time and analyzed by renaturing gel electrophoresis. This method has revealed the complexity of the autolytic system for the strain CNRZ 725, as at least 8 lytic bands were obtained in the profile: i) 1 at $121 \mathrm{kDa}$, very intense and which could correspond from the data presented here to the $\mathrm{N}$ acetylglucosaminidase activity mainly involved in the autolysis (Lemée et al, 1994b); ii) 6 lytic activities between 81 and $118 \mathrm{kDa}$ and iii) 1 relatively weak activity at $34 \mathrm{kDa}$. At this stage, it was not possible to assume that all these lytic activities corresponded to distinct autolysins. Some of them could correspond to proteolytically processed forms of the same autolysin, in particular the lytic activities with close molecular mass (between 81 and $118 \mathrm{kDa}$ ). Since the development of this renaturing gel electrophoresis method, autolytic systems which were supposed to be relatively well known, were, in fact, shown to contain many lytic activities: 8 lytic activities for $S$ aureus (Sugai et al, 1990); 11 for Klebsiella pneumoniae and 17 for $E$ coli (Bernadsky et al, 1994). The correlation between a lytic band and a specific autolysin is still an open question.

The attempts presented here to separate these 8 lytic activities and purify them by using classical methods such as ammonium sulfate precipitation, gel filtration and ionexchange chromatography have not resulted in extensive purification. Several difficulties were encountered, in particular the fact that the enzymes were always associated with cell wall neutral polysaccharides in high amount. For this reason, a method of direct extraction from whole cells was successfully developed, based on a $\mathrm{LiCl}$ treatment which had been previously described in the literature as an extracting agent for autolysins in several species (Bacillus subtilis [Ortiz et al, 1972; Rogers et al, 1984; Foster, 1992]; Streptococcus faecalis [Pooley et al, 1970]; Clostridium perfringens [Williamson and Ward, 1979] and Lactobacillus helveticus [Valence and Lortal, 1995]).

Further work implies i) the demonstration of the impact of propionibacteria autolysis on cheese ripening using strains highly prone to autolysis; ii) the purification, or at least, the separation of the 8 lytic activities constituting the autolytic system of $P$ freudenreichii CNRZ 725 in order to determine whether they are all distinct autolysins, and the definitive determination of which one corresponds to the $\mathrm{N}$-acetylglucosaminidase activity mainly involved in the autolysis of this strain (Lemée et al, 1994b).

\section{ACKNOWLEDGMENTS}

We are sincerely indebted to M Piot for amino acid analysis. We thank also friendly $F$ Valence "ès spécialiste électrophorèse"! This work was financially supported by Région Bretagne. 


\section{REFERENCES}

Baer A, Ryba I (1992) Serological identification of propionibacteria in milk and cheese samples. Int Dairy J2, 299-310

Bergère JL, Accolas JP (1986) Non-sporing and sporing anaerobes in dairy products. In: Anaerobic Bacteria in Habitats other than Man (EN Barnes, GD Mead, eds) Blackwell Scientific Publications, Oxford, UK, 373-395

Bernadsky G, Beveridge TJ, Clarke AJ (1994) Analysis of the sodium dodecyl sulfate stable peptidoglycan autolysins of select Gram negative pathogens by using renaturing polyacrylamide gel electrophoresis. J Bacteriol 176, 5225-5232

Bio-Rad (1987) HRLC columns for carbohydrate, alcohol, organic acid, and organic base separations. Bulletin 1373. Bio-Rad Laboratories

Bradford MM (1976) A rapid and sensitive method for the quantitation of microgram quantities of protein utilizing the principle of protein dye binding. Anal Biochem 72, 248-254

Brown WC (1972) Binding and release from cell walls, a unique approach to the purification of autolysins. Biochem Biophys Res Commun 47, 993-996

Brown WC, Fraser DK, Young FE (1970) Problems in purification of a Bacillus subtilis autolytic enzyme caused by association with teichoic acid. Biochim Biophys Acta 198, 308-315

Dawson RMC, Elliot DC, Elliat WH, Jones KM (1969) Preparation and composition of biochemical reagents. In: Data for Biochemical Research, Vol 1. 2nd edn, Univ Press, Oxford, UK, 615

de Carvalho AF (1994) Systématique des bactéries propioniques laitières: classification, nomenclature et identification. PhD Thesis, ENSA, Rennes, France

Dubois M, Gilles KA, Hamilton JK, Rebers PA, Smith F (1956) Colorimetric method for determination of sugars and related substances. Anal Chem 28, 350356

Dupuis C (1994) Activités protéolytiques et lipolytiques des bactéries propioniques laitières. $\mathrm{PhD}$ Thesis, ENSA, Pennes, France

Dupuis C. Boyaval P (1993) Esterase activity of dairy Propionibacterium. Lait 73, 345-356

Dupuis C, Corre C, Boyaval P (1993) Lipase and esterase activities of Propionibacterium freudenreichii subsp freudenreichii. Appl Environ Microbiol 59. 4004-4009

El Soda M, Macedo A, Olson NF (1991) Aminopeptidase and dipeptidylaminopeptidase activities of several cheese related microorganisms. Milchwissenschaft 46, 223-226

El Soda M, Ziada N, Ezzat N (1992) The intracellular peptide-hydrolase system of Propionibacterium. Microbios 72, 65-74
Foster SJ (1991) Cloning, expression, sequence analysis and biochemical characterization of an autolytic amidase of Bacillus subtilis 168 trpC2. J Gen Microbiol 137, 1987-1998

Foster SJ (1992) Analysis of the autolysins of Bacillus subtilis 168 during vegetative growth and differentiation by using renaturing polyacrylamide gel electrophoresis. J Bacteriol 174, 464-470

Foster SJ (1993) Analysis of Bacillus subtilis 168 prophage-associated lytic enzymes: identification and characterization of CWLA-related prophage proteins. J Gen Microbiol 139, 3177-3184

French CL, Milner HW (1955) Disintegration of bacteria and small particles by high pressure extrusion. Meth Enzymol 1, 64-67

Ingraham J (1987) Part 5: Growth of cells and cultures. Effect of temperature, $\mathrm{pH}$ water activity, and pressure on growth. In: Escherichia coli and Salmonella typhimurium. Cellular and Molecular Blology (FC Neidhardt, ed), American Society for Microbiology, Washington, DC, USA, 1543-1554

Jayaswal RK, Lee Y, Wilkinson BJ (1990) Cloning and expression of a Staphylococcus aureus gene encoding a peptidoglycan hydrolase activity. J Bacteriol $172,5783-5788$

Jolliffe LK, Doyle RJ, Streips UN (1981) The energized membrane and cellular autolysis in Bacillus subtilis. Cell 25, 753-763

Kemper MA, Doyle RJ (1993) The cell wall of Bacillus subtilis is protonated during growth. In: Bacterial Growth and Lysis: Metabolism and Structure of the Bacterial Sacculus (MA de Pedro, J-V Höltje, W Löffelhardt, eds) Plenum Press, New York, NY, USA, 245-252

Kurtz FE, Hupfer JA, Corbin EA, Hargrove RE, Walter HE (1959) Interrelationships between $\mathrm{pH}$, populations of Propionibacterium shermanit, levels of free fatty acids, and the flavor ratings of Swiss cheeses. $J$ Dairy Sci 42, 1008-1019

Laemmli UK (1970) Cleavage of structural proteins during the assembly of the head of bacteriophage T4. Nature (Lond) 227, 680-685

Langsrud T (1974) Proline production in propionibacteria. $\mathrm{PhD}$ Thesis, lowa State University, 10, USA

Langsrud T, Reinbold GW (1973a) Flavor development and microbiology of Swiss cheese-A review. II. Starters, manufacturing processes and procedures. J Milk Food Technol 36, 531-542

Langsrud T, Reinbold GW (1973b) Flavor development and microbiology of Swiss cheese-A review. III. Ripening and flavor production. J Milk Food Technol 36, 593-609

Leclerc D, Asselin A (1989) Detection of bacterial cell wall hydrolases after denaturing polyacrylamide gel electrophoresis. Can J Microbio/ 35, 749-753

Lemée R (1994) Le système autolytique de Propionibacterium freudenrejchii CNRZ 725 , bactérie propionique laitière. PhD Thesis, Université Rennes I, France 
Lemée R, Rouault A, Guezenec S, Lortal S (1994a) Autolysis of fifty-seven strains of dairy propionibacteria. Lait 74, 241-251

Lemée R, Cesselin B, Lortal S, van Heijenoort J (1994b) Involvement of an $\mathrm{N}$-acetylglucosaminidase in autolysis of Propionibacterium freudenreichii CNRZ 725. Appl Environ Microbiol 60, 4351-4358

Malik AC, Reinbold GW, Vedamuthu ER (1968) Evaluation of the taxonomy of the Propionibacterium. Can J Microbiol 14, 1185-1191

Morris MA, Holt C, Brooker BE, Banks JM, Manson W (1988) Inorganic constituents of cheese: analysis of juice from a one-month-old Cheddar cheese and the use of light and electron microscopy to characterize the crystalline phases. J Dairy Res $55,255-$ 268

Ortiz JM, Gillespie JB, Berkeley RC (1972) An exo- $\beta$ $\mathrm{N}$-acetylglucosaminidase from Bacillus subtilis: extraction and purification. Biochim Biophys Acta 289, 174-186

Pooley HM, Porres-Juan JM, Shockman GD (1970) Dissociation of an autolytic enzyme cell-wall complex by treatment with unusually high concentrations of salt. Biochem Biophys Res Commun 38, $1134-1140$

Potvin C, Leclerc D, Tremblay G, Asselin A, Bellemare G (1988) Cloning, sequencing and expression of a Bacillus bacteriolytic enzyme in Escherichia coli. Mol Gen Genet 214, 241-248

Rogers HJ, Perkins HR, Ward JB (1980) Microbial cell walls and membranes. Chapman and Hall, London, UK, 437-456
Rogers HJ, Taylor C, Rayter S, Ward JB (1984) Purification and properties of autolytic endo- $\mathrm{N}$-acetylglucosaminidase and the $\beta-\mathrm{N}$-acetylmuramyl-L-alanine amidase from Bacillus subtilis strain 168. J Gen Microbiol 130, 2395-2402

Salvat-Brunaud D, Maubois J-L, Le Graët Y, Piot M Maillard MB, Corre C, Thierry A (1995) Extraction et analyse de la phase aqueuse de l'emmental à 4 stades d'affinage. Lait 75, 239-249

Shockman GD, Höltje JV (1994) Microbial peptidoglycan (murein) hydrolases. Comprehensive biochemistry. In: Bacterial Cell Wall (JM Ghuysen, R Hakenbeck, eds) Elsevier, London, UK

Steffen C, Eberhard P, Bosset JO, Rüegg M (1993) Swisstype varieties. In: Cheese, chemistry, physics and microbiology. Vol 2: Major Cheese Groups, 2nd edn (PF Fox, ed) Chapman and Hall, London, UK, 83-110

Sugai M, Akiyama T, Komatsuzawa H, Miyake $Y$, Suginaka $\mathrm{H}$ (1990) Characterization of sodium dodecyl sulfate stable Staphylococcus aureus bacteriolytic enzymes by polyacrylamide gel electrophoresis. J Bacteriol 172, 6494-6498

Tunon P, Johansson K-E (1984) Yet another improved staining method for the detection of proteins in poly. acrylamide gels. J Biochem Biophys Methods 9,171 . 179

Valence F, Lortal S (1995) Zymogram and preliminary characterization of Lactobacillus helveticus autolysins. Appl Environ Microbiol 61, 3391-3399

Williamson R, Ward JB (1979) Characterization of the autolytic enzymes of Clostridium perfringens. J Gen Microbiol 114, 349-354 